RESEARCH NOTE

\title{
The Usefulness of Bergmann's Rule for the Distinction of Members of Lutzomyia intermedia Species Complex (Diptera, Psychodidae, Phlebotominae)
}

\section{Carlos Brisola Marcondes/ ${ }^{+}$, Ana Leuch Lozovei*, Eunice AB

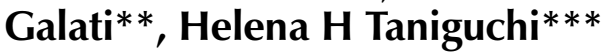

\author{
Departamento de Microbiologia e Parasitologia, CCB, \\ Universidade Federal de Santa Catarina, Campus \\ Trindade, 88040-900 Florianópolis, SC, Brasil \\ *Departamento de Patologia Básica, SCB, UFPR, \\ Curitiba, PR, Brasil **Departamento de
}

Epidemiologia, Faculdade de Saúde Pública, USP, São Paulo, SP, Brasil ***Seção de Parasitoses Sistêmicas, Instituto Adolfo Lutz, São Paulo, SP, Brasil

Key words: Lutzomyia intermedia - Lutzomyia neivai size - morphometry - Bergmann's rule

Bergmann's rule says that homeotherm animals from higher altitudes and latitudes, or bred at lower temperatures, tend to be bigger, and the validity of this rule to most studied ectotherms was noted by D Atkinson (1994 Adv Ecol Res 25: 1-58). RP Lane (1988 Geographic variation in Old World phlebotomine sandflies, p. 77-90. In MW Service Biosystematics of Haematophagous Insects, Clarendon Press, Oxford), made preliminary observations on the effect of temperature on the size of Lutzomyia longipalpis and CB Marcondes [1997 Morfometria e DNA Mitocondrial de Populações Sul Americanas de Lutzomyia intermedia (Lutz \& Neiva, 1912) (Diptera, Psychodidae, Phlebo-

\footnotetext{
${ }^{+}$Corresponding author. Fax:+55-48-331.9258. E-mail: cbrisola@mbox1.ufsc.br

Received 10 November 1997

Accepted 23 January 1998
}

tominae), $\mathrm{PhD}$ Thesis, UFPR, xxiv+260 pp.] observed that altitude and latitude also modify several dimensions of $L$. intermedia s. $s$. Moreover, RP Lane and G Fritz (1986 Syst Ecol 11: 439-445) observed that females of Phlebotomus papatasi are bigger than P. bergeroti females. However, the former occurs in lower altitudes than the other one, and they concluded that this apparent discordance from Bergmann's rule corroborates the distinction of these species.

Recently, CB Marcondes (1996 Mem Inst Oswaldo Cruz 91: 457-462) proposed the revalidation of $L$. neivai and distinguished it from $L$. intermedia s. s. To check this conclusion, we compared the size of specimens of L. intermedia s. $s$. from the eastern region of the State of São Paulo, between the "Serra do Mar" and the ocean (bellow $5 \mathrm{~m}$ a. s. 1.), with L. neivai from many localities at higher altitudes (500-800 $\mathrm{m}$ a. s. 1.) of the same state. It were obtained 39 measurements for each sex (Marcondes 1997 loc. cit.). Due to the current difficulty of differentiating males from these species (Marcondes 1996 loc. cit.), specimens were only included if associated to well identified females.

In the analysis of the results obtained, the significantly different measurements of insects of both species were calculated and shown in Table.

Although there was a great difference in the altitude of the two regions where the insects were collected, a small number of differences were noted. The dimensions of $L$. neivai were similar to those of L. intermedia s. $s$. If both belonged to the same species, according to Bergmann's rule, several dimensions of the former would probably be greater than those of the last. Therefore, our observations corroborate the differentiation between the species. As previously shown by Marcondes (1996 loc. cit.). L. neivai has greater dimensions in extragenital structures, while L. intermedia s. $s$. has greater dimensions in genital structures.

Some species of sandflies with very similar females, like L. shannoni and L. abonnenci, occur at different latitudes (DG Young \& M Duncan 1994 Mem Am Entom Inst 54: 881). The different proportions of $L$. wellcomei and L. complexa at several altitudes in the "Serra dos Carajás" (State of Pará, Brazil) indicated a greater epidemiological role of the first species (PD Ready et al. 1984 Trans $R$ Soc Trop Med Hyg 78: 543-544), and the differentiation of their females is very difficult. Measurements of the females of these insects should be obtained. The possible non-validity of Bergmann's rule to these pairs of species could help in their differentiation and corroborate their specific status. 


\section{TABLE}

Comparison between anatomical structures of specimens of both sexes of Lutzomyia intermedia s. $s$. from eastern lower localities of the State of São Paulo and of L. neivai from higher altitudes of the same state

\begin{tabular}{|c|c|c|c|c|c|c|c|c|}
\hline \multirow[b]{2}{*}{ Structures (in mm) } & \multicolumn{4}{|c|}{ L. intermedia s. s. (lower altitudes) } & \multicolumn{4}{|c|}{ L. neivai (higher altitudes) } \\
\hline & Mean & S. D. & $\mathrm{N}$ & C. V. & Mean & S. D. & $\mathrm{N}$ & C. V. \\
\hline \multicolumn{9}{|l|}{ Females } \\
\hline $\begin{array}{l}\text { Total length palps }{ }^{a} \\
\mathrm{a}^{a} \\
\mathrm{~b}^{b} \\
\text { Total length sperm. }\end{array}$ & $\begin{array}{l}334.7 \\
595.8 \\
309 \\
51.96\end{array}$ & $\begin{array}{r}22.63 \\
59.38 \\
59.19 \\
6.25\end{array}$ & $\begin{array}{l}43 \\
32 \\
32 \\
25\end{array}$ & $\begin{array}{l}6.8 \\
10 \\
19.2 \\
12\end{array}$ & $\begin{array}{l}347.2 \\
634.9 \\
279.1 \\
39.97\end{array}$ & $\begin{array}{r}23.19 \\
57.24 \\
29.65 \\
4.21\end{array}$ & $\begin{array}{l}61 \\
37 \\
37 \\
32\end{array}$ & $\begin{array}{c}7.5 \\
9 \\
10.6 \\
10.5\end{array}$ \\
\hline \multicolumn{9}{|l|}{ Males } \\
\hline $\begin{array}{l}\text { Length mesonotum }^{b} \\
\text { Length style }^{b} \\
\text { Length genital pump }\end{array}$ & $\begin{array}{l}499.6 \\
138.8 \\
213\end{array}$ & $\begin{array}{c}21.41 \\
9.46 \\
12.9\end{array}$ & $\begin{array}{l}31 \\
34 \\
34\end{array}$ & $\begin{array}{l}4.3 \\
6.8 \\
6\end{array}$ & $\begin{array}{l}517.7 \\
132.2 \\
190\end{array}$ & $\begin{array}{r}29 \\
5.78 \\
10.22\end{array}$ & $\begin{array}{l}59 \\
33 \\
77\end{array}$ & $\begin{array}{l}5.6 \\
4.4 \\
5.4\end{array}$ \\
\hline
\end{tabular}

S. D.: standard deviation; $N$ : number of specimens; C. V.: coefficient of variation; a: length of $R_{2}$; b: length of $R_{2+3}$; sperm.: spermatheca; $a$ : significant at $5 \%$; $b$ : significant at $1 \%$. 